Check for updates

UK Health Alliance on Climate Change

Cite this as: $B M J 2022 ; 376: 0608$ http://dx.doi.org/10.1136/bmi.0608 Published: 08 March 2022

\section{Should Western science institutions and scientists boycott their Russian equivalents?}

\section{Richard Smith chair}

The question inevitably arises whether Western universities, research institutes, journals, and scientists should refuse to have anything to do with their Russian equivalents because of Russia's unprovoked attack on Ukraine. Indeed, the Journal of Molecular Structure has already decided not to publish studies from Russian institutions, although it has no ban on individual Russian scientists both inside and outside of Russia. [1]

As I pondered the wisdom of a boycott, I remembered something I wrote in The BMJ in 2003, almost 20 years ago, about a possible boycott of Israeli science institution and scientists. [2] The core of the argument follows.

"Several hundred academics, including a few Israelis, have signed a petition that says: 'I can no longer in good conscience continue to cooperate with official Israeli institutions, including universities. I will attend no scientific conferences in Israel, and I will not participate as referee in hiring or promotion decisions by Israeli universities, or in the decisions of Israeli funding agencies.” This is a protest against the Israeli government's treatment of the Palestinians, and the emphasis is on boycotting institutions rather than individuals. Nevertheless, Mona Baker, a professor of translation studies in Manchester, has sacked two Israeli academics from her journal, and some editors have returned papers submitted by Israelis.

The BMJ deplores these actions and does not support any sort of boycott. Our position is based primarily on support for the 'universality of science,' which is enshrined in the International Council of Scientific Unions and explicitly rules out boycotts on the basis of citizenship, gender, religion, or colour. As four of Britain's most distinguished scientists wrote on 17 December in The Guardian, 'Although it is possible to imagine extreme circumstances in which the principle may have to give way to conflicting imperatives, the threshold to justify this is extremely high.' One such imperative might be the debasing of science, as happened in Nazi Germany. Nothing similar has happened in Israel. In contrast, groups like Israeli Physicians for Human Rights, which includes Jews and Palestinians, are working hard to draw attention to suffering on both sides of the tragic conflict."

The $B M J$ was against a boycott, and that would be my starting position now. But, as the piece says, there does come a point where the dreadfulness of what is being done may override the high value placed on the 'universality of science.' Has Russia reached that point with the horror of what it is inflicting on Ukraine? Many would think so.
A counter argument is that keeping contact with Russian scientists, at least some of whom must be appalled by what Russia is doing to Ukraine, may be helpful in finding a way out of this awful war. International Physicians for the Prevention of Nuclear War, which brought together Western and Russian doctors, won the Nobel Peace Prize for its contribution to ending the last Cold War and reducing the chance of nuclear war.

The International Paralympic Committee decided initially that it would allow Russian athletes to compete in the Winter Paralympics albeit not under a Russian flag because its core principles "include a commitment to political neutrality and impartiality." "Such neutrality," the Committee said, "is firmly anchored in the genuine belief that sport holds the transformative power to overcome our shortcomings, and summon from within us the best of our humanity, especially in the darkest of moments." [3] This argument is similar to the International Council of Scientific Unions principle of the "universality of science.” A day after its initial decision, however, the International Paralympic Committee reversed its decision under huge pressure from its members and international politicians. Scientists and science institutions may come under similar pressure.

Although I believe in the universality of science and the argument that all studies and data must be published to avoid distortion of science, I do not believe in political neutrality. I agree with Jonas Baer-Hoffman, a representative of international footballers, who says "The idea that we can make something apolitical is a myth.” [4]

Everything-including health, health care, sport, and science-is political however much we wish it wasn't. Crucially not being political is a political act.

It doesn't follow, however, that Russian scientific institutions and scientists should be boycotted: the best "political" response may be to maintain contact. But the West is responding to Putin's egregious and illegal attack on Ukraine not with conventional war, but with what the Financial Times calls a "new kind of 'hybrid war'-a combination of economic and soft power intended to punish Russia and pressure a change of course." [5] An unprecedented range of financial, business, sporting, cultural, and media organisations, including even the International Cat Federation, have cut ties with Russia.

If the West were fighting a conventional war against Russia then it seems likely that Western scientists would do everything they can to advance the war effort-as scientists worked to build the atomic bomb in the Second World War. If we now fight wars with economic and soft power, does it not follow that science institutions, including journals, should cut 
links with Russian institutions and perhaps even Russian scientists?

This dilemma could be focused on whether The BMJ should stop publishing studies from Russian institutions and even scientists and cut contact with them. I'm glad that I'm no longer the editor and don't have to decide.

Competing interests: Richard Smith was the editor in chief of The BMJ until 2004.

Provenance and peer review: not commissioned, not peer reviewed

1 Retraction Watch. Journal editor explains ban on manuscripts from Russian institutions https://retractionwatch.com/2022/03/04/journal-editor-explains-ban-on-manuscripts-from-russianinstitutions/

2 Some politics: against academic boycotts and for cheap drugs BMJ2003; 326:9 doi: 10.1136/bmj.326.7379.0/ghttps://www.bmj.com/content/bmj/326/7379/0.9.full.pdf

3 Sport BBC. Winter Paralympics 2022: Russia and Belarus athletes classed as neutral after Ukraine invasion. https://www.bbc.co.uk/sport/disability-sport/60586037

$4 \quad$ Financial Times. Uefa says 'impossible’ to say how Russia boycott will end. https://www.ft.com/content/a0525c15-a370-4b20-8f65-e10d667a9cdf

5 Financial Times. The west's hybrid war on Russia. https://www.ft.com/content/ff95ee3f-a1b84a54-9657-6a1aaecc105f 